\title{
State-building and Development Challenges: The Case of Armenia
}

\author{
Arpie Balian \& Nayiri Shorjian \\ American University of Armenia, Yerevan \\ College of Humanities and Social Sciences
}

Received 25 October 2018 - Revised 15 December 2018 • Accepted 19 December 2018

\begin{abstract}
The research explores the political, economic, social challenges and security priorities in state building in Armenia. It examines the government's efforts directed towards state-building, depicting the major challenges involved and exploring the framework of reforms that would measurably contribute to state-building. The study uses a qualitative explanatory research design based on content analysis of literature, interviews, a "roadmap" speech by the former president of the republic and the current government strategic plan. The study then focuses on state building primarily focusing on good governance and associated elements of democracy as prerequisites for a high-functioning state. The findings reveal a relationship between the quality of public institutions and state-building attributing the relatively slower democratization and state building progress to institutional deficiencies in governance. We claim that resolving each of the political, economic and social challenges separately would not lead to state-building. It is important to tackle the root causes of these challenges by focusing on increasing the capacity and efficacy of public institutions guided by the pillars of democracy and good governance.
\end{abstract}

Keywords: good governance, institutional capacity, state building, democratization, rule of law.

\section{Background}

Despite considerable national and international efforts expended in the past two decades - conceptualizing, analyzing, formulating and implementing various policies and development programs at different levels and with varied emphases - several countries of the former USSR continue to be underdeveloped. To this date, many of the post-Soviet states depict the symptoms of weak states (Riemer, 2005). The challenges that those CIS countries face vary considerably but may have a common thread of factors that runs through most, including high inequality (urban-rural and class inequalities), lack of adequate resources or uneven access to available resources, social exclusion, insecurity, etc. These challenges are usually elicited by the triggers as well as the consequences of weak governance caused by deficient or inexpert institutions, which have low functionality and fail to adequately manage the resources available in the respective country. Though there may be visible advances from time to time, sustainable statebuilding is almost out of reach in such malfunctioning circumstances as institutions play a crucial role in strengthening the state and improving productivity.

(C) Authors. Terms and conditions of Creative Commons Attribution 4.0 International (CC BY 4.0) apply. Correspondence: Arpie Balian, Professor, College of Humanities and Social Sciences, American University of Armenia, Yerevan, ARMENIA. E-mail: abalian@aua.am. 


\section{The concept of state-building}

Weak states have been at the center of the literature on state-building since 1990s, a period that has witnessed drastic changes in the world order when several new states emerged following the demise of the Soviet Union. Weak states are generally described as states whose public institutions lack the framework, capacity and determination to generate change for performing core state functions, particularly in providing the necessary public goods and services and for pushing forward development while safeguarding national security (Fritz \& Menocal, 2007; Karimi, 2012; Rotberg, 2003). Particularly after the Cold War, weak states invited the attention of scholars on the importance of state-building as a means of dealing with conflict and tackling post-war challenges, as well as securing economic and social development. Nevertheless, the adoption of a coherent model to help identify the most pressing issues in the process of statebuilding and differentiating among diverse reform priorities and requirements for pushing forward the weaker states continues to be challenging.

Until the 1990s, state-building was largely viewed as an internal process essentially initiated and driven by internal actors. However, beginning with the new millennium, a new wave of arguments emerged claiming that state-building is an exogenous process triggered by the international community in response to the socio-economic difficulties in the world (Berger, 2006; Karimi, 2012). Currently, scholars argue that although many external factors, such as donor impact, may be crucial to the onset or acceleration of the process, state-building is mainly the outcome of local dynamics (Fritz \& Menocal, 2007; Whaites, n.d.). In other words, state-building is a process that takes place as a result of national reform efforts and relevant programs that often extend beyond the borders of a given state.

A somewhat different view of the concept supports the argument that state-building is an internationally triggered local process that occurs in response to the emergence of weak states requiring attention by the international community (Fritz \& Menocal, 2007; Karimi, 2012). This view touches upon the notion of global governance and the mission of institutions and organizations to make transnational impact with the aim of regulating world order (Battacharya, 2001). However, scholars also propose that since the process of state-building takes place within the defined borders of a given territory, Weber's concept of legitimacy along with territorial authority can be viewed as essential variables to consider in studying state-building (Bogdandy et al., 2005; Brinkerhoff, 2006; Whaites, n.d.).

Despite the lack of consensus among scholars on the exact definition of the concept, state-building in its broadest sense is understood as the process of establishing or strengthening government institutions through reforms undertaken by national or international actors (Caplan, 2006; Fukuyama, 2006). The definition adopted by the World Bank places emphasis on the significance of reforms that improve governance, including adoption of mechanisms that increase accountability and government action in support of business and civil society (The World Bank Group, 2012). The most noteworthy push factor that has drawn international organizations into projects for building capacity and strengthening weak states is primarily driven by the desire to minimize undesirable spillover effects that produce hindrances to development in other parts of the world. These effects could range from epidemic ailments and poverty to mass migration and refugee settlement crises. From the standpoint of national priorities, however, state-building is directed more to achieving and preserving security, embracing the rule of law, delivering basic public goods and services, as well as establishing political legitimacy (Brinkerhoff, 2006). In the case of the latter factor, dominant approaches include growing the capacity of institutions and embracing the principles of good governance.

Without doubt, state-building priorities are contingent upon country specific circumstances (The World Bank Group, 2012). In fact, failure of state-building often arises because the model used by the respective country is not tailored to the specific circumstances and 
priorities of the state and, as a result, does not produce the intended outcomes (Eriksen, n.d.). Existing studies and especially evaluations of state-building lay out a rather dim picture of success attributing failures to the absence of the foundational elements of state-building. In line with that, some scholars advocate state-building requisites, such as national security, justice system, legitimacy and authority, and institutional capacity (International Dialogue on State-building \& Peace Building, 2013; McCandless et al., 2012; The World Bank Group, 2012).

\section{State-building v. nation-building}

In the current study, state-building is understood as "the set of actions undertaken by national and/or international actors to reform and strengthen the capacity, legitimacy and the institutions of the state where these have seriously been eroded or are missing" (Fritz \& Menocal, 2007: 13). This definition implies that understanding state-building requires a multidisciplinary approach, which, besides politics, may include other scientific principles.

In this regard, a confounding yet closely related concept to state-building is nationbuilding. A striking similarity between these two is that both can be achieved through indigenous efforts and reflect an ongoing iterative process. However, unlike nation-building, the concept of state-building in more recent literature makes reference to interventionist strategies for building the capacity of local institutions (Van de Walle \& Zoe, 2011). Though, as articulated by Fukuyama (2006), nation-building also may involve both reconstruction and development actions, but the difference is that state-building deals more with increasing the capacity of government institutions, whereas nation-building places emphasis on creating a sense of belonging through the construction of a collective national identity that embraces shared values and goals (Alesina \& Reich, 2012; Bogdandy et al., 2005; Fritz \& Menocal, 2007).

To define the concept, some scholars tend to limit the boundaries of nation-building to the distinct territory of a particular state (Bogdandy et al., 2005; Van de Walle \& Zoe, 2011). While this may be arguably true in the case of state-building where the main actors are public institutions within a state, restricting the process to a given territory may not reflect the real picture of nation-building particularly in the case of nations with active diasporic communities. The literature does not turn a blind eye to this phenomenon viewing it as another yet important approach to nation-building and collective identity construction - an approach that underscores the role of the Diaspora in shaping shared values and constructing the envisioned future for the nation (ADB, 2012; Shain \& Barth, 2003).

As Anderson (2006) posits, a nation is a socially constructed community, created by those who perceive themselves as part of a group (but not necessarily living within the same geographical boundaries). A nation, he argues, is often imagined because its members who may never know most of the other members or have met them or even heard of them. Yet in the minds of each of those who consider themselves a part of the group lives the image of their communion. It could be argued that diasporic communities that live apart shape the very communion that connects them with the nation. This commonness leads to the strength of a Diaspora and to the role its members may play in nation building and to the notion of stimulating attention to the dynamics of socially and culturally constructed processes relevant to nation building.

\section{Integrating good governance in state-building}

The earlier discussion of the differences between nation-building and state-building lends itself to placing more emphasis, in the case of the latter, on the performance of government institutions and issues of governance. The term governance began receiving renewed attention in development studies following the 1989 World Bank report entitled Sub-Saharan Africa: From 
Crisis to Sustainable Development. In the post 9/11 era and the upsurge of academic interest in interventionist strategies, attention drifted away from nation-building to state-building with an added focus on governance and socio-economic development. The world development attention centered on helping developing states build the capacity of their government institutions, improve the quality of public services, embrace good governance by way of increasing transparency and accountability, at the minimum. These building blocks continue to dominate topical debates and are no different from discussions of the importance and priority of building the framework essential for both development and state-building (DFID, 2006; Rondinelli \& Montgomery, 2005).

Governance is closely related to state-building as it encompasses the use of political power or authority, as well as the political system and institutions for administering state resources (DFID, 2006; Weiss, 2000). Moreover, good governance is often associated with aligning and improving a host of public management processes and procedures that would hinder state-building if not reformed. Most often, poor governance encompasses flawed institutions and, as such, it is an undeniable trigger of state failure (Ciborra \& Navarra, 2005; Rotberg, 2003).

According to the World Bank (1994), good governance encompasses four fundamental elements of state administration: public management, accountability, legal framework for development, as well as transparency and access to information. In fact, many of the weak states, such as Afghanistan, Iraq, and some African countries that have captured the attention of scholars in those elements of governance (Fukuyama, 2006; Himmelstrand, Kinyanjui \& Mburugu, 1994); Karimi, 2001). Thus, reform recommendations for state-building address improving elements of governance most essential for development.

Integral to good governance, corruption is regarded significant to state building, particularly affecting small and relatively weaker states. Pervasive forms of government corruption occur as bribes to government officials for permits and licenses, unnoticed passage through customs and for controlling markets by prohibiting market entry by new competitors (Shleifer \& Vishny, 2018) and other privileges available to the few. Depending on frequency and extent, corruption often occurs in the form of contracts, zoning or rezoning permits, and other sales of government goods and services awarded based on personal gain. Manifestations of corruption occur in various schemes, including restricting the supply quantity and maximizing the value of bribes throughout the chain of transactions, which generally go unpunished as several levels of government share the illicit proceeds. Not only do such unlawful actions deter competition, but severely restrict state revenues and slow down economic growth.

\section{The case of Armenia}

Overall, an appraisal of the key indicators of economic, democratic and social transition reveals a mixed record of reforms over the past decades, with slight progress in governance, but not in poverty and migration outflows. Although Armenia has made improvements on many fronts and in several sub-sectors or units of government, there remain serious challenges to overcome. A "key governance challenge in Armenia is corruption and the lack of genuine checks and balances" (USAID - Armenia website) ${ }^{1}$. The capacity of the RA civil service has improved to some extent, but often by growing its size and not necessarily improving quality and productivity (Balian, 2018). Despite efforts to reform the justice system and to reestablish the rule of law especially by the new government, enforcement continues to be challenging.

${ }^{1}$ https://www.usaid.gov/armenia, accessed in October 2017. 
An analysis of the indicators of sustainable economic growth, which incorporates poverty eradication and is an important element of state-building associated with government performance, shows that it has been rather slow and uneven between urban and rural communities of Armenia. According to official data, the poverty rate in Armenia fell by only $0.4 \%$ from 2008 to 2016, almost stagnating at around 30\% (National Statistical Service of RA, 2017). Multiple crises have emerged within financial markets and the banking sector, currency instability and inflation, energy security, and other economic and social issues against the persistent background of border security challenges. Armenia is constrained geopolitically in terms of its closed borders, relations to the North and South, and the strategic challenge of balancing between East and West. All three of these factors impact state development and require latitudes and strategies that minimize resultant constraints.

The Armenia Development Strategy 2014-2025² points to development issues that address many critical bands needing reform while integrating the macroeconomic, productive, and social dimensions of development. Those strategies aim at increasing the level of diversification and technological might of the national economy to create reasonable levels of employment on a sustainable basis, while promoting social equity and, to some extent, environmental protection. Among the underscored challenging strategies of state-building is the improvement of Armenia's governance, in general, with emphasis on improving the quality and effectiveness of public goods and services, sustainability of development through the transparent allotment and use of government resources, consorted collaboration among government institutions, as well as accountability to the public.

Moreover, the components included in the recent EU-Armenia Comprehensive and Enhanced Partnership Agreement (CEPA) (signed on 25 November 2017) duly reflect several of the challenges of state-building identified in the analysis above. These can be headlined under economic, safety and security challenges, reforms in the legal system, human capital development and human rights protection, and public participation in policy-making. CEPA promotes business competition and entrepreneurship by way of creating a business climate that facilitates business investments and improves the enforcement of rules and regulations especially pertaining to competition and transparency of decision-making related to business support. More importantly, CEPA contains a cross-cutting component of institutionalizing transparency and accountability across government.

This approach is aligned with the new government's priority strategy for establishing justice throughout the branches of government. The guiding principle, articulated consistently and coherently by the current government, is that all citizens and institutions are subject to and accountable to the law enforced fairly across all segments of the population. This is bound to have positive consequences on the general climate in the country. Embracing the rule of law and the establishment of a fair judiciary system create an environment where transparency and accountability in all spheres become feasible. Thus, despite the recent changes in the ruling party and quasi coalition government that has held in the first one hundred days of the new government, the key challenges to state-building in Armenia remain relatively unchanged.

\section{Research design and methodology}

The current research on the state-building challenges of Armenia begins with an analytical synthesis of the situation and public perception before the Velvet Revolution of AprilMay 2018, which toppled the government and brought to power the challengers. The study comprises a review of preceding articles, reports, and key documents, duly referenced,

${ }_{2}^{2}$ A new draft of the Armenia Development Strategy 2018-2030 was submitted for review in April 2018. 
complemented by a qualitative explanatory analysis of the "roadmap" speech by former President Sargsyan (delivered on 12 February 2016, highlighting the state strategic focus under the revised RA Constitution) and seven (7) expert interviews conducted in the months of October and November 2017.

Considering the timing of the change in the system of government from semipresidential to parliamentary coupled with the 2018 Velvet Revolution that altered the mosaic of parties and the executive council of government ministers, the analysis touches upon the most striking state-building components that have been visibly affected. A more thorough assessment of the events related to the Velvet Revolution and what has followed calls for further research.

Selection of the qualitative methodology and the data sources considered for the current research aim at identifying the building blocks of state-building and the key challenges viewed from diverse perspectives. The collected data have provided the opportunity to depict more implicitly the roles that public institutions play in the process of state-building, whilst bearing in mind the role of civil society and the Diaspora.

Purposive sampling was used in selecting the interviewees to include public sector officials, representatives of major Diaspora organizations and international experts. This strategy afforded the collection of data from sources that represent maximum variation. The advantage afforded by purposive sampling was the involvement of individuals from various backgrounds, different perceptions of the role of principals and agents in state-building, and levels of current engagement in politics. This approach enriched the quality of data and diversity of opinions. The interview questions were formulated from the analysis of the literature presented earlier in the article.

\section{Analytical synthesis of existing challenges of state-building}

\subsection{Political challenges}

Until recently, the key political challenge continued to be the absence of true checks and balances in the system compounded by a powerful executive that undermines the burgeoning institutions and agents of democratic accountability (USAID, 2017). According to the Freedom House report (2016), Armenia's progress has been very slow over the past decade in all of the seven indicators of democracy with a current democracy score of 5.39 (on a scale of 1 to 7 , where 1 represents the highest level of democratic progress and 7 the lowest) 3 . The democracy index comprises indicators of national and local democratic governance, electoral process, civil society, independent media, judicial framework and independence, and corruption. The 2018 Freedom House report, published earlier in the year, shows the best score to be civil society at 3.75 (the scores for national democratic governance, electoral processes and local democratic governance are the worst, with 6.00 in case of the first two and 5.75 for local democratic governance). While all other indicators have remained the same in the past year, the score of corruption has leveled up by 0.25 from 2017 to the first trimester of 2018 when the Freedom House report was published. Therefore, along with true checks and balances, corruption is found to be a critical hindrance to state building in Armenia.

Despite the former government's commitment to reform and some positive changes that have taken place in this domain in the recent past, there remain many challenges related to the pillars of democracy, mainly in growing an accountable and transparent government, as well as institutionalizing participatory policy-making. The civil service has limited capacity in terms of achieving substantially higher performance. Also, adequate checks and balances among the executive, legislative, and judicial branches need to be enforced and continually reinforced to

3 https://freedomhouse.org/report/nations-transit/2018/armenia, accessed in July 2018. 
institutionalize democratic governance principles, policies and practices. Above all, however, of utmost significance for Armenia is the difficulty of finding a sensible balance in tackling national security concerns and encouraging openness considering the scarcity of resources and the lingering burden of the continuing conflict with neighboring Azerbaijan.

Citizen participation in decision-making and public debate has been low historically at both national and local levels (Babajanyan, 2008). In general terms, popular agreement with the country's reform agenda has been limited to party affiliation and individual favorable position vis-à-vis government. How then would the country move on in this domain and what are the action items to consider? Does the answer lie in the 2016 roadmap speech by former President Serzh Sargsyan and efforts by his administration or should one look deeper into the usual expressions of various other political actors, such as the current head of state, Prime Minister Nikol Pashinyan and his rhetoric on the urgency of "changing the way we govern?". This is a question that merits attention, at the minimum for understanding the level of government commitment to statebuilding. Was the official position by the former president reflective of the state strategic agenda or were those assurances and commitments just lip service meant to shape public opinion, to possibly increase trust in his leadership and hope in the future of Armenia?

Public protests against corruption in government - perceived to be endemic - have often been organized by opposition parties and activists, which eventually reached a highpoint at the Velvet Revolution in April 2018. The criticality of getting a dominant majority of the populace to fight against corruption at all levels could not be disputed. In the first instance, however, efforts are necessary for government to increase the transparency of decisions in various units and functions (e.g. budget allocations and public expenditures, procurement decisions, and subsidies). More importantly, taking the bold step of exercising the rule of law by punishing a few grand corruption cases rather than removing them from the limelight or public scrutiny would set the tone of government commitment to the fight against corruption.

In the case of Armenia, it is also important not to put aside the historical and geographical factors that play into the process of development. Scholars have argued that development challenges often stem from history (and geography) and that is the reason why one needs to consider those in their respective political and cultural contexts (Himmelstrand, Kinyanjui \& Mburugu, 1994); Karimi, 2012). The blockade with neighboring Turkey, as well as the continuing Karabakh conflict with Azerbaijan, have placed enormous strains on state resources creating barriers to growth, often shifting development priorities to first addressing security challenges.

\subsection{Institutional and civic challenges}

Armenia's primary challenges in this sphere rest in building institutions and statesociety relations for government to deliver public goods and services that meet public needs and expectations and safeguard legitimacy. The latter largely relates to the extent to which government possesses or acquires governance capacity and technical expertise for doing so. Issues of governance related to "reducing poverty, strengthening human rights, securing gender equality, realizing the rights of children and youth, combatting and preventing corruption, improving accountability, and greater political participation" (GIZ, 2015: 1), must be addressed through systems and programs that improve the wellbeing of society. Good governance challenges also embrace checks and balances that would institutionalize cross-checks among the branches of government thereby improving the quality (fairness, transparency and verifiability) of decisions throughout government.

Moreover, the regulatory platform is laden with onerous regulations, deficient institutional capacity, and archaic processes that further hamper the effectiveness of the civil 
service triggering rising public discontent. Further, cronyism and political patronage continue to hamper the collective capacity of government often impeding development and exacerbating the uneven and flawed enforcement of regulations and ineffective delivery of public services. While the former government was run by consensus reached among the ruling elite with limited mechanisms and opportunities for civic participation into the legislative process or policy making and monitoring of implementation (USAID, 2013-2017), the current transitional government is yet to institutionalize channels of civic participation in decision-making processes.

While acknowledging that respect for human rights has grown significantly and the work of the RA Human Rights Defender has been supporting a progressively enhanced human rights agenda, there are visibly disadvantaged segments in the population, such as women and others, who are discriminated against or fall victim to different forms of violation, including gender-based inequities; unequal access to economic and political resources; limited participation in public life; and relatively lower political representation (in spite of the quota established by the RA Constitution). A positive step in this realm was the ratification of the RA Law on Domestic Violence (passed by the RA National Assembly in December 2017), which has not yet shown signals of large-scale positive differences - differences that would stem from educating the public at large and empowering them to drive cultural and social change.

There are over 5,000 registered non-governmental organizations (NGOs) in the Republic, which do not yet translate into an organizationally strong and active civil society (EU, 2014-2017), although positive signs are noticeable in the recent past. Observations of the activism in recent months lead to the preliminary assumption that opportunities to engage in policy discussions with decision-makers and legislators may be increasing, changing the culture of citizen participation in political life. However, a significant portion of the population continues to be disengaged or misinformed. Though the Freedom House report (2018) assigns the best score to civil society commending the growing pluralism of public discussions (including the media) in Armenia, ownership of the media rests primarily in the hands of people affiliated with political parties (including the opposition), which raises questions on the quality and objectivity of content.

\subsection{Economic challenges}

Although the economic challenges of Armenia predominantly stem from the world economic order, the slow growth cannot be solely attributed to external factors and forces. At the internal front, challenges are observed to be derived from the rates of advancement in human capital and social capital development in Armenia. Scholars argue that both human capital and social capital are reliable predictors of the rate at which a country grows its economy. Moreover, creating linkages between these two forms of capital is believed to augment human potential. "Social capital brings to the force the social networks and values through which skill portfolios generally are built, deployed and rewarded" (Schuller, 2000: 18). Accordingly, dominant social norms, networks, and relations among community members and social groups act as enablers for realization of the human potential (Balian \& Aydinyan, n.d.).

In 2017, GDP growth in Armenia outperformed expectations, recording the highest rate of growth in the past decade at $7.5 \%$ after a flat economic performance in 2016. Growth was driven mainly by a recovery in the external environment and supported by a strong rebound in domestic demand. Consumption benefited from higher incomes and a recovery in remittances, particularly due to the moderate recovery in Russia. According to the RA National Statistical Service, the absolute value of the GDP in 2016 was US $\$ 10.5$ billion, which grew up to US $\$ 11.6$ billion in 2017 recording a growth of 7.5\%. This is the highest growth in the last 10 years (National Statistical Service of RA 2017). "Growth was driven mainly by a recovery in the external environment and supported by a strong rebound in domestic demand. Consumption benefited 
from higher incomes and a recovery in remittances, particularly due to the moderate recovery in Russia" (The World Bank, 2017).

Moreover, a positive trade balance was recorded primarily attributed to the increase of exports by 21\%. According to the RA Minister of Agriculture, the volume of fruits and vegetables increased by $21 \%$ in 2017 , leading to an $11 \%$ increase in the volume of processed fruits and vegetables. Of special significance was the 30\% increase of exports of locally-produced wine (The State Revenue of the Government of Armenia, 2017). Despite these positive developments in the recent year, Armenia is not yet on the road to sustainable growth capable of creating a strong labor market where skill supplies are better aligned with demand. The key policy challenges are measures that "invest in education, skills and infrastructures, encourage competition and strengthen governance" (IMF, 2017: 9).

The earlier years of economic growth have produced uneven and unequal distribution of wealth rather than real improvement in living standards for most of the population. Widening disparities in wealth and income have led to a serious socioeconomic divide on several levels, most notably between rural and urban areas. These disparities also have promoted migration and have widened the gap between the rich and the poor. In fact, statistics reveal that the ten wealthiest citizens of Armenia control more than 55 percent of the total wealth in the country (USAID, 2013). According to the World Bank, poverty reduction and income growth are likely to stagnate during 2017-2018 in Armenia (WB, 2016). Improvement of the business environment in a manner that specifically addresses the growth of small and medium enterprises appears to be a more serious challenge than originally thought. It is critically important to focus on strategies that fashion a strong middle class.

\section{Data analysis and discussion}

Within the framework established by the theories of state building, as discussed above, content analysis was performed of the presidential roadmap speech (delivered by the former president on 12 February 2016, soon after the constitutional referendum of December 2015), of the new government plan published on June 1, 2018, and of the transcripts of expert interviews ( $n$ $=7$ ) conducted in November-December 2017. The analysis applied thematic coding of text focused on revealing and examining dominant patterns within the expressed terms and phrases relevant to the challenges of state-building.

The label 'democracy' and its various pillars dominate the Presidential speech as well as the government plan of 2018, and are also articulated by the interviewees in varying intensities and terms, such as freedom, equal opportunity, free and fair elections, protection of human rights and individual freedoms, freedom of political assembly, etc. While the former President places added attention on public participation in his speech, underscoring that "even the most selfconfident officials cannot reject cooperation with those who want to bring their participation to our state-building process" (Sargsyan, 2016), the government plan of 2018 additionally places specific emphasis on, free and fair elections and depicts zero tolerance for corruption as a precondition for establishing democratic values and practices.

Overall, the rule of law, security and institutional capacity are the most dominant themes in the interviews (7/7), in the former President's speech (Sargsyan, 2016), as well as in the 2018 government plan of the new administration, all of which place emphasis on these components as necessary preconditions for heightening the impact of government. The discourse markers used for valuing the rule of law encompass the fairness of legal decisions, harmonization of laws and associated legal provisions with the RA Constitution, as well as components of good governance, such as transparency, consistency of actions across government and accountability. Along similar lines, the former President's speech and the government plan refer to key indicators 
of justice, such as transparency and predictability of court decisions, accountability to the citizenry, and the prevalence of the rule of law across the entire populace.

Although those are pillars of democracy, the former President's reference to the rule of law was meant more than just advocating for building the Armenian modern democratic state. Particularly in the segment of the speech where he focuses on economic growth, the rule of law argument is fundamental to assuring that "no one should be above the law" and that "all citizens shall have equal opportunities" (Sargsyan, 2016). Similar expressions can be found in the very first segment of the $\mathbf{2 0 1 8}$ government plan where one of the goals underscored is "national unity and solidarity based on the rule of law and equality before the law."

Closely associated with state-building priority challenges, most interviewees $(6 / 7)$ raised at least one security concept to be the lead challenge of state-building considering Armenia's relations with its neighbors to the east, south-west and west. The constructs brought forth under the security theme encompassed diplomatic relations, national armed forces, border protection and external security (although internal security was not altogether left aside). These phrases were often used in the government plan but with intended importance attached to internal security by the former President and by the interviewees interchangeably and were meant to emphasize the importance of national security for a country in conflict, be it through soft power and strategic alliances or by way of a strong army to protect state borders and the citizenry.

Most interviewees (5/7) addressed the importance of institutional capacity of the government in the delivery of public goods and services that meet citizen needs. This, they asserted, also involves adopting the right strategic direction and implementation of projects that are integral to state-building. Moreover, interviewees spoke about the positive impact on performance of the right level of expertise and specific job-related competences in the civil service. Adoption of the merit system, some added, would increase the transparency of recruitment, promotion and retention and increase government productivity. As one interviewee articulated “... public institutions would be more effective if civil servants were hired on the basis of merit rather than by consideration offactors that are more often not transparent and based on connections". Expounding the concept of adopting a meritocratic civil service system, interviewees explained that fair and transparent hiring affords equal opportunities to all interested applicants and realizes the recruitment of the most qualified.

Speaking of the pillars of state-building, the interviewees (6/7) appraised the former government's achievements in judicial reform as inadequate. Moreover, two interviewees placed emphasis on educational reform; and one specifically mentioned the importance of civil service reform. A slight discrepancy is observed between the dominant discourse in the pillars and the suggestion of most urgent reforms. In discussing the pillars, emphasis was placed on the effectiveness of public institutions and security, however in the most urgent reforms civil service reform was downgraded and reforms in the military were not at all mentioned. However, the importance given to the judiciary system is not surprising as the most recent government plan places equal emphasis on establishing justice in Armenia through independent judiciary system.

In tune with the literature review, public institutions were viewed as having a major role in state-building. All (7/7) interviewees asserted that public institutions play a crucial role in state-building, with two taking the extreme position that "there would be no state without strong public institutions", placing added emphasis on the role of public institutions in relations with the public and the Diaspora. In other words, the strength of a state lies in the efficacy and capacity of its institutions in building participatory relationships with the public and the Diaspora.

The interviews also depicted a dominant pattern regarding the role of civil society in state-building. Most of the interviewees (5/7) attributed a secondary role to civil society explaining that in the case of Armenia, civil society lacks the capacity to sufficiently contribute to statebuilding due to the lack of or insufficient knowledge/awareness of policy options and political 
maturity. Civil society was mostly seen as "a referee to watch over government accountability and transparency" in matters especially related to the rule of law, justice, and overall performance. Two (2/7) interviewees also spoke about important preconditions for civil society to take shape, get established and " $d o$ its job" in state-building, including exercising more tolerance. "Although Armenian civil society is a proponent of inclusion and participatory policy-making, it is itself as intolerant as the government". Further, the understanding of democracy or its practice, for instance "the idea of unity often referred to in Armenian political discourse seems to be outdated". This suggests that state-building would require better focus on developing civil society capacity and acumen, so it would become a principal actor itself. There are signals of recent positive change in this realm and further changes seem to be possible based on the most recent government plan, which places much importance on civil society and its participation in the process of strengthening the state.

As to the Diaspora and its role in state-building, the former President's speech addresses this under the rubric of "one nation", affirming that "The Diaspora and Armenia represent one unity, the nation. Diaspora's right to participation in Armenia is considered (in the state-building roadmap) and fostered" (Sargsyan 2016). Similarly, most interviewees (6/7) posit that there is a role for the Diaspora, but one that is not associated with any specific segment, community, organization or party, but relates to all diasporans "who can contribute to the motherland through education and expertise". The expressed argument that defends this notion is that anyone should be able to support the state in its development efforts and democratic reforms, without necessarily being supportive of the ruling elite or the inordinate power it exudes. This is a spot-on concern that very much relates to the current political situation in Armenia. One interviewee added that the previous administrations often influenced the participation of political parties, considering that "Diaspora parties have expectations of political gain from the $R A$ government", which often shapes their support of the ruling elite and does not necessarily contribute to state-building.

Democracy was the connecting link among the state-building notions brought forth in the interviews, in the former President's speech, and in the 2018 government plan. A weak democracy was denoted as one with a weak media, absence of rule of law, and inadequate flow of information both vertically and horizontally. Utmost importance was attached to the prevalent weaker or politicized media that propagates negative publicity and impairs state-building (6/7). Further, the media was viewed as an important channel for increasing public awareness and access to information. Media continues to be highly politicized in the post revolution era, where dissemination of misinformation continues to be a major obstacle to effective state-citizenry relations. Oddly, only a few respondents (3/7) spoke about insecure borders as a major deterrent that "obstructs the path to successful state-building". Social capital was not viewed as a contributor to state-building; rather, poverty, migration and corruption were deemed important but viewed as consequences of low state capacity and not as challenges to state-building.

As for the indicators of successful state-building, several interviewees (4/7) stressed the significant weight attached to the quality of governance, including the respective individual and collective capacity of public institutions, which shapes the understanding and practice of transparency and accountability. Governance directly affects the quality of delivered public goods and services; therefore, it influences the level of citizen satisfaction. This is the reason why it is an important pillar of state-building. This, the interviewees claim, also is linked to migration outflows, which weakens the state. As citizen satisfaction increases, migration outflows decrease. One interviewee went further, elaborating that "successful state-building could also translate to an inflow of migrants". Governance is believed to also encompass "a supportive legal framework" as affirmed by the former President, the current government and the rule of law that delivers "equal opportunities to all citizens". 
Economic development was another challenge mentioned by a few interviewees (3/7) but dependent upon the success achieved in the other elements discussed earlier. In other words, the results achieved in this sphere would be rather slim, insignificant and unsustainable for achieving a stable economy absent the rule of law, security and institutional capacity. This viewpoint is also shared by the current Prime Minister and his government. Evidently, in a weaker state, economic advances would be limited to the expansion of a small number of enterprises and would not grow a middle class critical to sustained growth.

\section{Interpretation and conclusion}

The analytical synthesis completed in the first phase of the current research, combined with the data analysis of interviews, the former President's speech and the 2018 government plan reflect important notions that are supported by the literature on this topic. The results shed light upon the major challenges to state-building that Armenia currently faces and discuss prospects with respect to minimizing these challenges and taking the path to achieving successful statebuilding.

Extracting from the literature, state-building in the broadest sense refers to the strengthening of public institutions, though this is not explicitly stated in the interviews, in the former President's speech or in the 2018 government plan, but it is frequently implied. The economic, political and social challenges discussed earlier largely stem from the inadequacy of the performance of public institutions. Hence, the proposed reforms cannot be achieved but through the concerted efforts of respective institutions and commitment by all.

The literature discusses Weber's legitimacy as an important variable or a requisite for state-building. In line with this notion, an immense effort to strengthen the government's political legitimacy can be observed in the former President's speech as it frequently emphasizes the elements of democracy, such as justice, transparency, rule of law and participation of the citizenry in decision-making. All these indicators contribute to the consolidation of trust between the government and citizens, which in its turn positively influences the legitimacy of the government. Legitimacy was a recurrent concept in the interviews as well, as "satisfaction of the citizens" was mentioned as an important indicator (but not a requisite) for measuring successful state-building.

The frequent reference to the rule of law, accountability and participation, especially both in the former President's speech and in the 2018 government plan, shows that the main challenges to state-building in Armenia are closely attached to these constructs. Taking into consideration the literature on good governance and state-building, there is a natural overlap between the main pillars of democracy and the elements of good governance. In other words, although accountability, equal opportunity and transparency are mentioned within the context of democracy, they also contribute to successful state-building by way of increasing the quality of performance of public institutions.

Closely linked to institutional capacity, the lack of meritocracy in the civil service is seen as a pressing issue not only by the interviewees, but also in the words of the former President. Lack of meritocracy was also frequently brought up during and right after the Velvet Revolution. This suggests that continuing reforms are critically needed in this area and must go beyond simply making positive changes to the law to increasing commitment, to adopting new rules and regulations that govern the "way government works". Moreover, judicial reforms, as suggested by the interviewees and inferred in the former President's speech, as well as in the 2018 government plan, are as important for state-building considering that adherence to laws has direct impact on public trust and prepares ground for social, economic and political reforms initiated by the government. 
The former President's speech attaches a primary role to the reciprocal roles of government and citizenry in the process of state building, placing considerable emphasis on the participation by civil society in policy-making. Importantly, the current government is making effort to create channels of communication between the government and the public to facilitate citizen participation in decision-making. Conversely, the interviewees portray civil society as incapable of constructively and effectively participating in state building, though it is now impossible to deny the power of the people that has been duly manifested in the Velvet Revolution. But, earlier arguments stretch beyond simply empowering the citizenry to creating the necessary platforms to grow awareness of and interest in public policy-making. Any analysis of such arguments advocates that civil society is an important resource for any country; in the case of Armenia the general lack of transparency, absence of communication channels (vertical and horizontal) and fixation on distrust have hindered civil society from "doing its job".

Moreover, the other obstacles to state-building found in the literature and discussed earlier, mainly migration and poverty, are found to be consequences rather than causes of a weak state. This may explain why state efforts directed to mitigating migration and poverty do not necessarily lead to successful state-building. Contrary to prevalent criticisms, more effort should be expended towards implementing elements of good governance, such as transparency, accountability, institutional capacity building and establishing a legal framework for development, all of which are mentioned in the 2018 government plan, rather than artificially accelerating growth. If economic growth is viewed as an indicator of successful state-building, it is mostly so when achieved through good governance and not irrespective of the capacity currently eminent in government institutions.

There is no single model of state-building that fits all sizes. State-building and its pillars are very much country specific. In other words, unless the model is tailored to the social, political, economic and geopolitical conditions and context of the country, being successful at state-building may be difficult to achieve.

\section{Acknowledgements}

This research did not receive any specific grant from funding agencies in the public commercial, or not-for-profit sectors.

The authors declare no competing interests.

\section{References}

Anderson, B. (2006). Imagined Communities: Reflections on the Origin and Spread of Nationalism. New York, USA: Verso.

Asian Development Bank Armenia (2006-2011) (2012). Retrieved from: https://www.adb.org/documents/armenia-country-strategy-and-program-2006-2011-final$\underline{\text { review }}$

Babajanian, B. V. (2008). Local Governance in Post-Soviet Armenia: Leadership, Local Development and Accountability (by request from the author).

Balian, A. G. (2018). Increasing State Capacity and Legitimacy through Civil Service Reform.

Balian, A. G., \& Aydinyan, V. (n.d.). Social Capital: The Crucial Link for Optimizing the Impact of Human Capital. 
A. Balian \& N. Shorjian - State-building and Development Challenges: The Case of Armenia

Battacharya, M. (2001). Globalization, Governance and Development. The Indian Journal of Political Science, 62(3). Special Issue on Globalization and the State: 349-357.

Berger, M. (2006). From Nation-building to State-Building: The Geopolitics of Development, the NationState System and the Changing Global Order. Third World Quarterly, 27(1), 5-25.

Bogdandy et al. (2005). State-Building, Nation-Building and Constitutional Politics in Post Conflict Situations:

Conceptual Clarifications and an Appraisal of Different Approaches. Max Planck Yearbook of United Nations Law, 9, 579-613.

Brinkerhoff, D. (2006). Governance in Post-Conflict Societies: Rebuilding Fragile States. Routledge, London.

Caplan, R. (2006). Internal Governance of War-Torn Territories: Rule and Reconstruction. Oxford University Press, Oxford.

Chesterman, S. (n.d.). From State Failure to State-Building: Problems and Prospects for a United Nations Peacebuilding Commission.

Ciborra, C. \& Navarra, D. (2005). Good governance, development theory, and aid policy: Risks and challenges of e-government in Jordan. Information Technology on Development, 11(2), 141159.

Department for International Development (2006). Governance, Development, and Democratic Politics.

Emerson, R. (1959). From Empire to Nation: The Rise of Self-Assertion of Asian and African Peoples. Harvard: Harvard University Press.

European Union (2014). Armenia: EU Country Roadmap for Engagement with Civil Society 2014-2017. Retrieved From: https://eeas.europa.eu/sites/eeas/files/20141027 eu armenia cs roadmap en o.pdf.

Freedom House (2016). Nations in Transit. https://freedomhouse.org/report/nations-transit/nationstransit-2016. Accessed in June 2017.

Fukuyama, F. (2006). Nation-Building Beyond Afghanistan and Iraq. Baltimore: John Hopkins University Press.

Fukuyama, F. (2004). The Imperative of State-Building. Journal of Democracy, 15(2), 17-31.

Fritz, A., \& Menocal, A. R. (2007). Understanding State-Building from a Political Economy Perspective. Report for DFID's Effective and Fragile States Teams. Overseas Development Institute.

GIZ (2015). The Key Issues of good governance: A coherent approach for greater impact and efficiency. Retrieved from: https://www.giz.de/en/downloads/giz2015-en-good-governance-keyissues.pdf

Himmelstrand, U., Kinzanjui, K., \& Mburugu, E. K. (1994). In Search of New Paradigms. In: U. Himmelstrand et al. (Eds.), African Perspectives on Development: Controversies, Dilemmas and Openings. E.A.E.P., Nairobi.

International Monetary Fund (July 2017). Republic of Armenia Selected Issues. Report No. 17/227. Washington, D.C.

Karimi, K. (2012). Challenges to State-Building Efforts in Fragile States: Lessons from Afghanistan Post 2001. Retrieved from: http://www.natowatch.org/sites/default/files/challenges to statebuilding efforts in fragile states - kaveh karimi.pdf.

National Statistical Service of Armenia (2017). Armenia: Poverty Profile in 2008-2016.

Retrieved From: http://armstat.am/file/article/poverty_2017_english_2.pdf.

Republic of Armenia, The State Revenue Committee (2018). Retrieved from http://finport.am/full news.php?id=33186\&lang $=3$ 
Riemer, A. K. (2005). The Concepts of State-building, Nation-building and Society Building. Academic and Applied Research in Military Science, 4(3), 367-379.

Rondinelli, D., \& Montgomery, J. (2005). Regime change and Nation-Building: Can Donors Restore Governance in Post-Conflict States? Public Administration and Development, 25, 15-23.

Rotberg, R. (2003). Failed States, Collapsed States, Weak States: Causes and Indicators. In: When States Fail: Causes and Consequences: 1-25.

Sargsyan, S. (2017). President Serzh Sargsyan's Remarks on the Implementation of the Constitutional Changes. Retrieved from: http://m.president.am/en/statements-andmessages/item/2016/02/12/President-Serzh-Sargsyan-meeting-Constitution-speech/

Shleifer, A. \& Vishny, R. W. (2018). Corruption. The Quarterly Journal of Economics, 108(3), 599-617.

Schuller, T. (2000). The complementary roles of human and social capital. Manuscript, Birkbeck College, University of London.

Shain, Y. \& Barth, A. (2003). Diasporas and International Relations Theory. International Organization, $57(3), 449-479$.

The World Bank Group (2012). Guidance for Supporting State-Building in Fragile and Conflict-Affected States: A Tool-Kit.

USAID (August 2013). Country Development Cooperation Strategy FY 2013-2017.

Retrieved from: https://www.usaid.gov/sites/default/files/documents/1863/ArmeniaCDCS.pdf.

Wendt, A. (1994). Collective identity formation and the international state. American Political Science Review, 88(2), 384-396.

Weiss, T. (2000). Governance, Good Governance and Global Governance: Conceptual and Actual Challenges. Third World Quarterly, 21(5), 795-814.

Whaites, A. (2008). States in Development: Understanding State-Building. Governance and Social Development Group Policy and Research Division.

World Economic Forum (2016). The Human Capital Report. 
A. Balian \& N. Shorjian - State-building and Development Challenges: The Case of Armenia 